\title{
DIRECTIONS OF THE STATE POLICY OF HEALTHCARE REFORM IN UKRAINE
}

\author{
Sergii O. Kravchenko ${ }^{1}$ \\ Vitaliy V. Shpachuk ${ }^{2}$
}

\begin{abstract}
Today in Ukraine, the theme of health care is extremely relevant and painful for most Ukrainian society. The Ukrainian healthcare system has a low level of financial and material security, a technically backward infrastructure, imperfect management, requires significant financial investments, and the use of innovative management and medical technologies that the state cannot provide due to the crisis and limited budget. Therefore, the topic of health care is one of the most discussed in society, because health care concerns everyone without exception, a citizen of our state, which is why the process of formation and implementation of state policy in the field of health today is almost the most important issue in Ukraine. In view of this, the article analyzes the state of the healthcare system of Ukraine, the current state policy of Ukraine in the field of health care. The features and drawbacks of the modern healthcare system of Ukraine, the difficulties faced by the state in
\end{abstract}

the process of reforming the healthcare system are highlighted. The necessity of changing the existing healthcare system as a prerequisite for the following changes in this area, the preconditions of European integration development of Ukraine, achievement of modern health standards, based on the current realities of Ukraine's existence, national interests, ongoing system changes in Ukraine, as well as needs state and society. The directions of the state policy of healthcare reform in Ukraine have been determined, and it has been proved that the reform of the medical sphere requires significant changes in the socio-political, financial-economic, administrative-territorial, legal and other spheres of state activity.

Keywords: state policy, healthcare reform, healthcare management, decentralization, health financing model, health education system.

\footnotetext{
${ }^{1}$ Department of Public Governance and Administration, Educational and Research Institute of Management, Economy and Ecology, V.I. Vernadsky Taurida National University, 01042, 33 D. Makkein Str., Kyiv, Ukraine. E-mail:

s.kravchenko5514-3-1@ust-hk.com.cn

${ }^{2}$ Department of Public Governance and Administration, Educational and Research Institute of Management, Economy and Ecology, V.I. Vernadsky Taurida National University, 01042, 33 D. Makkein Str., Kyiv, Ukraine.
} 


\section{I}

\section{in}

GÊNERO E

INTERDISCIPLINARIDADE

\section{INTRODUCTION}

Over the past decades, the concept of "health" has acquired an essential political significance. Governments, public or private organizations, by means of policy measures, are trying in every way to find effective levers of influence on individual and public health in order to improve its status. Increasing the participation of governments and interest groups in developing policy decisions on health care, increasing the attention of scholars of different fields of knowledge to this area is not accidental. After all, the issue of health (or lack thereof), the cost and availability of treatment, the proper living conditions concern the interests of large groups of people, form electoral mood, become the subject of political debate. Therefore, it can be said that doctors have lost the monopoly on the regulation of the healthcare system, and the policy of health has become the subject of political research. The most relevant in this discourse are questions about the goals and directions of healthcare reform in terms of financing this area and distribution of funds, its legislative regulation, organization of medical care, management of the healthcare system, etc.

New requirements for healthcare policy are also linked to the objective process of
Vol no 02 | no 01 | ISSN: 2675-7451

https://www.periodicojs.com.br/index.php/gei/index

forming a holistic world - globalization. In today's world there is a globalization of health problems, which are actively politicized at the same time. The epidemic of HIV / AIDS, tobacco smoke and drug addiction, tuberculosis, hepatitis, obesity, and the like in various countries has become the subject of political discourses at the national and global levels. Pandemics (global epidemics) of infectious diseases pose a threat to countries and are increasingly in need of immediate response to national health systems. It is enough to mention the latest outbreaks of the Ebola virus from 2014 to 2015, from which thousands of people died in different countries of the world (Scientists ..., 2015).

On the other hand, supportive structures and international public organizations that play the role of global actors in the public health policy are increasingly involved in solving health problems. However, the implementation of international obligations, standards, programs and model health legislation in specific countries depends to a great extent on the expediency of social and medical interventions, and on endogenous political factors such as the local context, socio-cultural and political traditions, and ideological preferences. Such modern political innovations lead to a deeper understanding of the processes of the relationship between national and supranational political institutions 
in the healthcare sector, current governance trends and the impact of global initiatives on specific policy areas.

\section{MATERIALS AND METHODS}

In our opinion, the issue of healthcare reform should be considered in several respects. Using the analysis method, it was found that for a long time in Ukraine, the healthcare system has long exhausted itself and today does not meet the needs of the state and society. This system was called "comprehensive model Semashko", and was developed after the Second World War. The purpose of this system was the fight against infectious diseases and injuries, which in general were the result of external causes, but not determined by personal behavior; care for mother and child health issues. The system was owned and financed by the state, it was aimed at maintaining hospitals, with extremely fragmented management, and services focused on the treatment of individual non-serious acute conditions and the actual lack of prevention.

The consequence of such state policy is the state's maintenance of a cumbersome network of hospitals - 2200 hospitals and more than 400 thousand hospital beds in the public sector, which is significantly higher than in the countries of the European Union as a whole, while public health financing is carried out in proportions comparable with European ones, but does not pay for services received by patients. According to statistics, every year in the sphere of health comes about 3 billion UAH taxes paid by Ukrainian citizens, but about 640 thousand Ukrainian families have to pay for expensive treatment of serious illness independently while undergoing a financial crash (The Reform Office ..., 2019).

For this study, statistical data were used, according to which Ukraine ranks second in Europe (after Belarus) by the number of hospital beds per capita, has almost twice as many hospitals and clinics as in Germany, but they are extremely ineffective. According to the World Bank, for 40 million inhabitants, in Ukraine, health care costs per person are 149 US dollars. In Germany, where the population is 81 million inhabitants, the cost of health care per person is 4,800 US dollars (Kovtonuk, 2015). In addition, the "false" financing of "beds and hospitals" is far from the only problem of the existing healthcare system in Ukraine. It continues to remain closed to international healthcare modernization practices, has significant areas of ineffective functioning and corruption, is too centralized and has ineffective management, numerous fragmented sets of outdated healthcare institutions, unable to provide citizens with efficient and high-quality 
Vol no 02 | no 01 | ISSN: 2675-7451

services, etc.

Comparison of organizational, legal, financial, managerial, economic, structural, personnel, informational and other fundamental errors that prevent Ukraine from achieving a significant increase in human capital was carried out (The Draft National Strategy..., 2014). All this is happening despite the fact that Ukraine spends considerable budget funds on health care. It should also be noted that experts attribute the existing difficulties in reforming the healthcare system by:

- reforming takes place under conditions of general economic crisis;

- there is no clear vision of the desired model of healthcare system;

- the reform of this system is not marked by a holistic approach to ensuring the health of the nation, but concerns only the purely medical industry and practically does not take into account other areas of health impact (Avramenko, 2015; Suhrcke et al., 2008).

\section{RESULTS AND DISCUSSION}

The analysis of the domestic and foreign state policy of reforming the healthcare sector made by us makes it possible to assert that it should not be defined as a separate activity, but should be organically embedded in the processes of social transformations aimed at improving the quality of life of citizens. In the Encyclopedia of Public Administration, quality of life is understood as a complex integral characteristic of the status of a person in society, an indicator of the extent of its social freedoms and opportunities for comprehensive development, satisfaction of material and intangible needs (Petroe, 2011). The world's most well-known integral indicator of the quality of life of the people is the UN Human Development Index.

This Index includes, among other things, the estimated life expectancy at birth, reflecting the effectiveness of the healthcare system, and hence the corresponding policies. According to the data of 2017 in Ukraine, this indicator was 72.1 years, which is about 10 years less than in the leading countries of the world $\quad(82-84 \quad$ years $) \quad$ (Human Development ... 2018). Consequently, an increase in the expected life expectancy at birth can be an indicator of the success of healthcare reform. In Ukraine today, the cardinal changes not only in this sphere but also in many other spheres of public life are taking place in order to introduce generally accepted democratic standards of public administration and life. That is, the vector of the socio-political process in Ukraine demonstrates the desire to transform our country into a developed state with European standards of living standards, freedoms, protection of the population, 


\section{I}

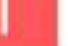

GENERO E

INTERDISCIPLINARIDADE

creation of comfortable living conditions for its citizens, etc.

Taking into account the above, the need for revision and improvement of the state policy of reforming the healthcare sector in Ukraine corresponds to the logic of sociopolitical transformations of modern Ukraine. At the same time, radical reformation of the medical sphere also requires significant changes in the socio-political, financialeconomic, administrative, legal and other spheres of state activity. It is necessary to understand that healthcare reform policy can only have a social effect in the case of coordinated transformations in other areas of the state's activity, especially in the implementation of state policy in the social, economic, financial, and administrativeterritorial changes. Mentioning exactly these areas of activity of the state is conditioned by direct mutual influence, interconnections and interdependence of these spheres and the sphere of health care. The reform of the healthcare system cannot be successfully carried out without the introduction of simultaneous and even forward-looking transformations in the implementation of the mentioned directions of the state policy.

In the process of reforming any public sphere, it is necessary to take into account the inextricable link between the system of public administration and the system of local self-
Vol no 02 | no 01 | ISSN: 2675-7451

https://www.periodicojs.com.br/index.php/gei/index government. Bodies of state administration and local self-government create a system complex consisting of bodies of different nature, but integrated into an organizational whole, the need to ensure the implementation of practically the same administrative functions and powers of the state executive power on the ground (Sharov, 2001). In this regard, it should be noted that the reform of healthcare management institutions should include the coordination of transformations in executive authorities with existing and potential transformations of local selfgovernment and aim at creating an effective healthcare system at the regional and local levels. Thus, in reforming the organization and activities of the system, it is impossible to ignore the systemic transformations that take place today in the sphere of organization of relations between the system of state executive bodies and local self-government, namely the implementation of a decentralization policy.

The goal of decentralization policy is to transform local governments into a real entity at the territorial level, which should be provided with powers and resources in solving local problems. In addition, the logic of the process of decentralization itself involves the mobilization of citizens' activity, the growth of the role and importance of free choice of the local community itself when making managerial decisions and ways of their 


\section{। \\ ।}

GÊNERO E

INTERDISCIPLINARIDADE

implementation, including the right to dispose of the funds provided for it. Citizens get the opportunity and ability to determine the priorities of local life by themselves, choose the ways and means of their achievement. It is on this and it is necessary to pay attention to the reformers at the implementation of the territorial level of the planned transformation.

Extremely important is the creation of a nationwide network of health facilities distributed across the country. Proven reformation involves the creation of a holistic system of health care, consisting of three links (primary care, secondary and tertiary), but when distributing the network of medical institutions of these units in the territories comes not from the administrative-territorial division and the formed united territorial communities, but tied to the established hospital districts and relies on hospital councils. This, on the one hand, will facilitate the unification of medical establishments of the hospital district into a coherent system, on the other hand, it can become the basis for conflict of interests and increase of competition between communities for allocation of resources. At the same time, the attachment of medical reform to the ongoing changes in the organization of power at the territorial level puts it in direct dependence on the results of the implementation of the policy of decentralization, makes an indefinite period
Vol no 02 | no 01 | ISSN: 2675-7451

https://www.periodicojs.com.br/index.php/gei/index

of its implementation and threatens to succeed.

Of course, the condition for the success of the state policy of reforming the healthcare sector in Ukraine is also its agreement with the state's activities in other areas. The introduction of health insurance will require the preparation of financial and legal support, the establishment of appropriate state financial infrastructure, as well as the development of models and networking with the banking sector and insurance companies. The organization on the basis of the new principles of the healthcare system as a component of social protection of Ukraine provides for the adoption of new standards, which, accordingly, requires the revision of modern state social standards. Significant transformations require legal and regulatory support for both the direct activities of the doctor and the basic principles of state policy in the field of health, etc., as reflected in the Constitution and laws of Ukraine. Mature conceptual transformations proposed by the proclaimed healthcare reform must be consolidated in the legal field of our state in order to create the legal framework for a new health system.

The success of the reform will help to take into account the current trends in the medical sector of the EU. As noted by researchers O. Vashev, A. Vasheva and L. Ivanova, nowadays in most European 


\section{I

countries more and more attention is paid to prevention and sanitary-hygienic education of the population, and not to the process of treatment as such. Although it is emphasized that, as before, more than half of all health care costs go from 50 to $75 \%$ in hospitals in the EU (Vashev, 2017). Scientists also emphasize that the development of health care in Europe is based on the widespread use of new information technologies and research results, which creates a new foundation for the development of health care (Vashev, 2017). Taking into account the ongoing processes of decentralization and development of civil society, it is necessary to emphasize the need to introduce methods of active interaction of public authorities with non-governmental organizations and citizens in the processes of management of the healthcare sector in Ukraine.

It is also important to ensure the motivation and ability of health professionals and managers to work in new environments. This means, first of all, a clear explanation of the content and the formation of a positive perception of reforms among these workers. Another direction is the creation of a quality health education system in accordance with international standards. In this regard, the Cabinet of Ministers of Ukraine approved the Strategy for the Development of Medical Education in Ukraine, which envisages the
Vol no 02 | no 01 | ISSN: 2675-7451

https://www.periodicojs.com.br/index.php/gei/index creation of a sectoral system of qualifications, updating of the content of higher and professional advanced medical education on the basis of a competent approach, introduction of effective forms of integration of education and science in the field of health care, strengthening the practical component of the training of health professionals, etc. (On approval ..., 2019).

In addition, by the order of the Ministry of Health of Ukraine No. 1977 of October 31, 2018, amendments were made to the Directory of qualification characteristics of professions of workers. Issue 78 "Health Care" (On Amendments to the Directory ..., 2018; Karlova et al., 2019; Hornyk et al., 2018; Bilynska and Radysh, 2013; Law of Ukraine No. 2801-XII, 1992; Law of Ukraine No. 2168-VIII, 2017; Law of Ukraine No. 2206-VIII, 2017; Order of the Cabinet of Ministers ..., 2016; Decree of the President of Ukraine No.55/2020, 2020). According to these changes, among the qualification requirements for persons who can hold positions of healthcare managers (general director (director) / chief (head) of the healthcare institution, deputy director general / director / chief (manager) the institution of health care), the existence of an educational master's degree in the field of knowledge "Management and Administration" or "Public management and administration" or "Social 


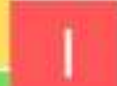

- GENERO E

INTERDISCIPLINARIDADE

and behavioral sciences" is determined. Taking into account this, particular attention should be paid to the creation of an effective nationwide system of training healthcare managers capable of fully implementing the objectives of the reform of this area.

\section{CONCLUSIONS}

The implementation of the state policy of reforming the healthcare sector of Ukraine includes a number of areas that are the basis and integral parts of its implementation, in particular:

- development at the national level of an integrated strategy of social reforms, correlation of reform activities between its components;

- reconciliation of changes in the medical sphere with the logic of the modern political process, as well as changes in other areas of state activity;

- taking into account the systemic changes taking place today in the sphere of organization of relations between the system of bodies of state executive power and local selfgovernment;

- the real introduction of a new health financing model based on the principle of "money going by the patient", which should replace the ineffective model of payment for beds;
Vol no 02 | no 01 | ISSN: 2675-7451

https://www.periodicojs.com.br/index.php/gei/index
- providing a leading role to communities not only in defining the forms and methods of organizing the local system of medical institutions, but also at the disposal of allocated allocations;

- creation of a qualitative system of training specialists and managers in the field of health in accordance with international standards;

- establishment of cooperation and mutual understanding between the legislative branches (in the person of the Healthcare Committee of the Supreme Council of Ukraine) and the executive branch (represented by the Ministry of Health of Ukraine) by the branches of government;

- consolidation in the legal field of our state of overdue reforms, including changes to the Constitution and laws of Ukraine, legal and regulatory support for both the activities of the doctor and the principles of state policy;

- taking into account the current trends in the medical sector of the EU countries and so on.

Further research deserves the definition of the peculiarities of the implementation of the state policy of reforming the healthcare system taking into account the specifics of the regions of Ukraine.

\section{References}




\section{। \\ GENERO E \\ INTERDISCIPLINARIDADE}

Avramenko, T.P. Observance of Public Health

Warranty as the Basis of Public Administration by Changes the Healthcare in Ukraine. Bulletin of the National Academy of Public Administration under the President of Ukraine. Series "Public Administration", 2015, 2, 4350.

Bilynska, M. M., Radysh, Y.F. State policy in the field of health care. Kyiv: NADU, 2013.

Decree of the President of Ukraine No. 55/2020 "On the Interim Working Group on Health Care Reform", 2020, February. https://zakon.rada.gov.ua/laws/show/55/2020 \#Text.

Hornyk, V.G., Kravchenko, C.O., Bakumenko, V.D. Development of public administration in Ukraine: theoretical, methodological and practical aspects. Kyiv: UkrSICH, 2018.

Human Development Indices and Indicators. Statistical Update. UNDP (United Nations Development Program). New York: Communications Development Inc., 2018. http://hdr.undp.org/en/content/humandevelopment-indices-indicators-2018statistical-update

Karlova, V.V., Honiukova, I.V., Kravchenko, S.O., Shpachuk, V.V., Hornyk, V.G., Simak, S.V., Vasilevska, T.E., Parubchak, I.O. Development of mechanisms of good governance in Ukraine: challenges and
Vol no 02 | no 01 | ISSN: 2675-7451

https://www.periodicojs.com.br/index.php/gei/index

prospects. Lviv-Toruń: Liha-Pres, 2019.

Kovtonuk, P. Developers of the Strategy of Healthcare Reform advise to prepare to Insurance System just now, 2015. http://lada.fm/2015/01/20/gotuvatisya-dostrahovoyi-sistemi-vzhe-sogodn-radyatrozrobniki-strategyi-z-reformuvannyaohoroni-zdorovya.html

Law of Ukraine No. 2168-VIII "On state financial guarantees of medical services to the population”, 2017, October. https://zakon.rada.gov.ua/laws/show/216819\#Text.

Law of Ukraine No. 2206-VIII "On Improvement of Accessibility and Quality of Health Care Services in Rural Areas”, 2017, November.

https://zakon.rada.gov.ua/laws/show/220619\#Text.

Law of Ukraine No. 2801-XII "On Fundamentals of the legislation of Ukraine on Healthcare", $1992 \quad$ November. https://zakon.rada.gov.ua/laws/show/280112\#Text.

On Amendments to the Directory of Qualification Characteristics of Professions of Workers. Issue 78 "Health Care". Order of the Ministry of Health of Ukraine, No. 1977, 2018, October 31. Ministry of Health of Ukraine, 2018. http://moz.gov.ua/article/ministrymandates/nakaz-moz-ukraini-vid-31102018-- 
Vol no 02 | no 01 | ISSN: 2675-7451

https://www.periodicojs.com.br/index.php/gei/index

GENERO E

INTERDISCIPLINARIDADE

1977-pro-vnesennja-zmin-do-dovidnika-

kvalifikacijnih-harakteristik-profesij-

pracivnikiv-vipusk-78-ohorona-zdorovja

On approval of the Strategy for the

Development of Medical Education in

Ukraine. Regulation of the Cabinet of

Ministers of Ukraine, No. 95-p, 2019,

February 27. Cabinet of Ministers of Ukraine,

2019. http://zakon.rada.gov.ua/laws/show/952019-\%D1\%80

Order of the Cabinet of Ministers of Ukraine No. 1013-r "On approval of the Concept of health care financing reform", 2016, November.

https://zakon.rada.gov.ua/laws/show/10132016-\%D1\%80\#Text.

Petroe, O.M. Strategic Planning in public governance. In Encyclopedia of Public Administration. Vol. 1, Kyiv: Publishing house "NADU", 2011.

Scientists: Ebola Virus Mutates - BBC, 2015. http://www.unian.net/world/1037621-

uchenyie-virus-ebola-mutiruet-bbc.html

Sharov, Yu.P. Strategic Planning in Municipal Management: Conceptual Aspects. Kyiv: Publishing house "UADU", 2001.

Suhrcke, M., Rocco, L., McKee, M. Investments to the health: the key condition of successful economic development of the cee and Central Asia countries. Copenhagen:
WHO Regional Office for Europe, 2008.

The Draft National Strategy of Forming of the New Healthcare System in Ukraine on 20152025 , 2014. http://www.apteka.ua/article/315522

The Reform Office. The Consultative Body under the Cabinet of Ministers of Ukraine. Health Care, 2019. http://rdo.in.ua/direction/ohorona-zdorovya Vashev, O.E., Vasheva, A.O., Ivanova, L.A. Modern trends in change policy of medical care providing in EU countries. In Proceedings of the XVII International Scientific Congress Public Administration in XXI Century: Traditions and Innovations (pp. 295-298). Kharkiv: Publishing house "Magistr", 2017. 